\title{
Comparison between Biogas Concentrations Emitted by Two Open Landfills: Truitier (Haiti) and Gabarre (Guadeloupe)
}

\author{
V. Pierre-Georges", F. Bade, J. Molinié \\ Research Laboratory in Geosciences and Energies, University of the French West Indies (French) Campus of Fouillole, France
}

Copyright $\mathrm{C} 2017$ by authors, all rights reserved. Authors agree that this article remains permanently open access under the terms of the Creative Commons Attribution License 4.0 International License

\begin{abstract}
Household and related wastes management become a real problem in modern society. The increasing amount of waste led to use more and more waste incinerators and landfills. In underdeveloped countries, most of the collected garbage is left in uncontrolled open landfills. The open landfill, with flying plastic and biogas emission, creates nuisance for the neighboring environment and population. The main gases produced by waste decomposition are VOCS (Volatile Organic Compounds) and hydrogen sulphide $\left(\mathrm{H}_{2} \mathrm{~S}\right)$. In our study located in Haiti and Guadeloupe, we used hydrogen sulphide as a tracer gas to determine the impact on the environment and human health. Our measurement campaign was both held in Haiti and Guadeloupe. In the controlled garbage dump of Gabarre (Guadeloupe), a portion is completely replanted, and the other hand receives all types of waste. The biogas from the garbage dump Gabarre is channeled into pipes, which will be burned by flare. The uncontrolled garbage dump of Truitier (Haiti) is only controlled by the scavengers. They put the waste in fire, and all the sites are under a smoke plume. To evaluate the emission of gas, we have to identify the center of the landfill and the measurement point rentals. The points have been selected downwind of the landfill taking in account the average local wind direction, in order to observe the gas evolution of the garbage dump. We observed from the performed concentration of $\mathrm{H}_{2} \mathrm{~S}$, a same belt behavior for both sites with low concentration soon in the morning, a maximum raised around midday, followed by a decrease during the afternoon. This observed behavior suggest year influence of sun energy on the emission rate. With the maximum concentration, the intensity and the direction of the wind, we calculated the emissivity reported to a central point. We compared their emissivity taking in account the daily amount of waste, the total surface of the landfill and the waste composition ratio. With these first results, we evaluated and compared the concentration of the biogas and their impact on neighboring populations in
\end{abstract}

Port au Prince (Haiti) and Guadeloupe.

Keywords Landfill, Garbage, Biogas, $\mathrm{H}_{2} \mathrm{~S}$ Emission

\section{Introduction}

In developing countries and even in developed countries, the management of waste is linked to the political, social and economic development of the country. They have become a real problem for the environment and human health, with situations often dramatic in developing countries [7]. The waste generated by households and industrial activities produce pollutants that may be dangerous to the flora and fauna. The toxic gas and leachate from the anaerobic degradation of organic waste can be released respectively in the atmosphere and groundwater, thus affecting human health. In addition to human toxicity, biogases from landfill sites have an impact on the global warming due to their participation in greenhouse effect. Therefore, the management of waste has become a crucial issue in our modern society.

In addition to waste minimization initiatives there are also efforts to reduce the quantities of priority pollutants in the waste stream. These dispositions have included banning the disposal of household hazardous waste [14]. Landfill gas is produced continuously by microbial action on biodegradable wastes under anaerobic conditions. Methane and carbon dioxide are the major constituents of landfill gas and greatly contribute to the greenhouse effect [13]. However, the impact of certain trace gases on the environment and potentially on human health may be more significant than that of the bulk gases (e.g. $\mathrm{CH}_{4}$ and $\mathrm{CO}_{2}$ ). Over 500 compounds have been reported in landfill gas [13], such as VOCs and the mercaptans specially hydrogen sulfide $\left(\mathrm{H}_{2} \mathrm{~S}\right)$ one of the most toxic gases.

The presence of $\mathrm{H}_{2} \mathrm{~S}$ in landfill gas is problematic for several reasons, it's corrosive to landfill gas collection and 
treatment systems, it has a low odor threshold (0.02 ppm $0.13 \mathrm{ppm})$ and it's toxic and presents challenges for occupational safety in enclosed areas [8].

In the context of assessing the impact of the waste on the environment, we have measured the concentrations of $\mathrm{H}_{2} \mathrm{~S}$ in the vicinity of two (2) landfills Truitier in Haiti and Gabarre in Guadeloupe.

We have used the hydrogen sulphide $\left(\mathrm{H}_{2} \mathrm{~S}\right)$ as trace gas to determine the impact on the ambient air of biogases linked to the presence of the landfills.

According to the World Health Organization (WHO), occupational exposure limit values of $\mathrm{H}_{2} \mathrm{~S}$ is $7 \mathrm{ppm}$ over 8 hours of work adopted by many governments[19], 1ppm in America[3] and 5ppm in Europe[6]. In order to evaluate the emission of hydrogen sulphide in the vicinity of landfills, we have proceeded by inverse modeling of the Gaussian model to determine the maximum potential concentration of $\mathrm{H}_{2} \mathrm{~S}$ that could occur near landfills. The traditional modeling approach approved by the US EPA is based on the traditional stationary Gaussian model to predict the hourly concentration of conservative pollutants at different distances from the source [2].

We have calculated the total emissivity of gas from the landfill to estimate the biogas concentration and to assess the impact of the latter on the neighboring populations. In comparison with the Gabarre, we found different results and must verify the impact of the fire of landfills on concentrations of $\mathrm{H}_{2} \mathrm{~S}$. To improve the impact of the gas of landfills on the environment and human health, we believe propose new patterns of collection and treatment of waste within the meaning Caribbean.

\subsection{Gabarre's Landfill}

The Gabarre's open landfill is the main one in Guadeloupe. It is a place of garbage treatment since 1973, and created by the institutional directive, with an initial area of 5ha. It has reached 37ha in 2015 [17] with and exponential increase and located in the municipality of Abymes east to the salted river and north of the Gabarre Bridge [16].

Gabarre's landfill receives 215,000 tons of waste every year, which constitutes a major source of anthropogenic pollution surrounding areas. It is located in a mangrove area that surrounds it. The mangrove is bordered by marine sites: the protect sites of Le Grand Cul de Sac Marin (North) and Le Petit Cul de Sac Marin (South) and on the West side by the Salt River [17].

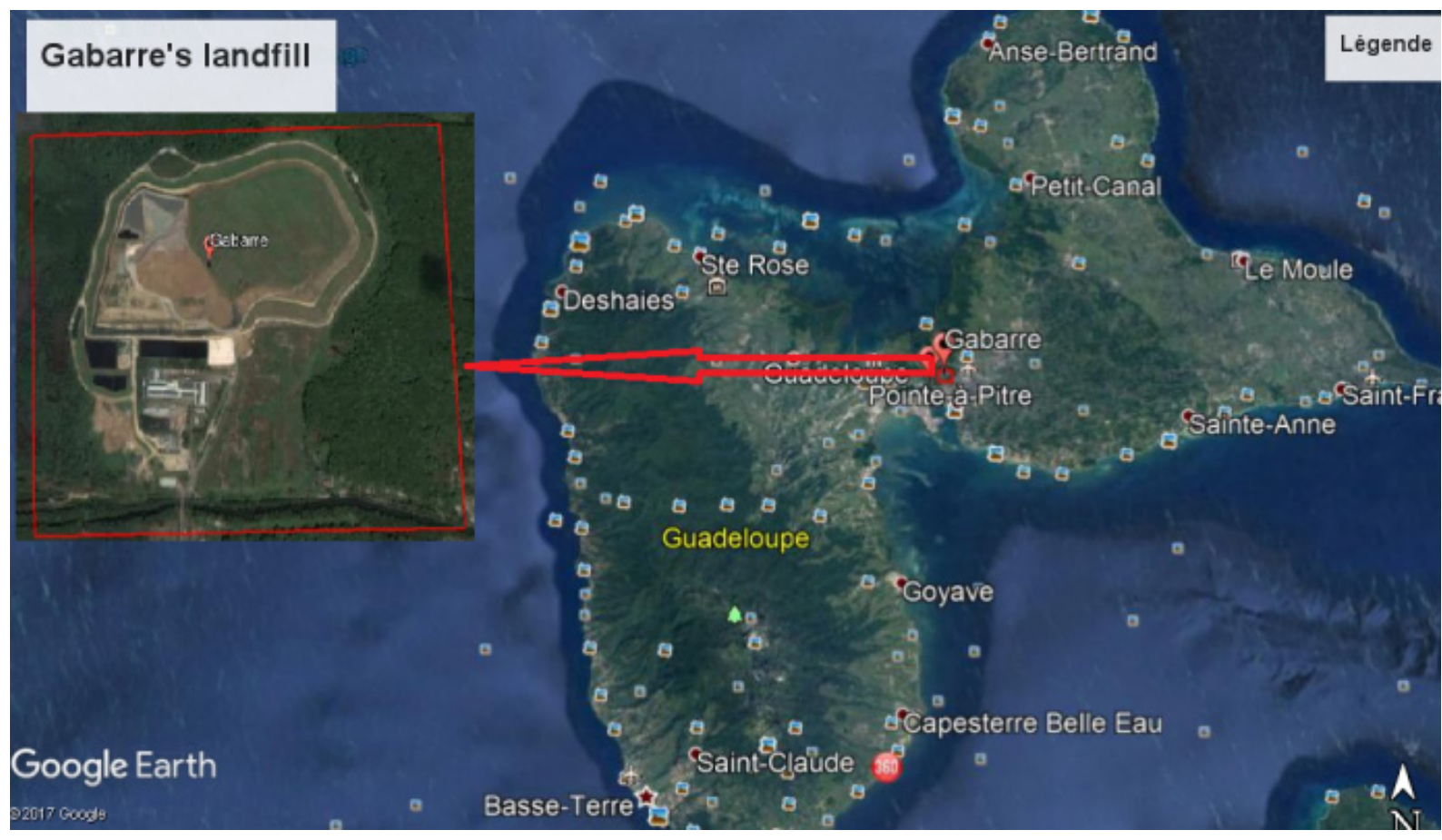

Figure 1. Gabarre's landfill location

Table 1. Quantities of waste collected by the communities from 2010 to 2014 in Guadeloupe [9]

\begin{tabular}{|c|c|c|c|c|c|}
\hline Years & 2010 & 2011 & 2012 & 2013 \\
\hline Tonnages collected & 199041 & 246193 & 236547 & 231620 \\
\hline Annual evolution & & $+24 \%$ & $-4 \%$ & $-2 \%$ & 574 \\
\hline $\mathrm{Kg} / \mathrm{Ca} /$ year & 493 & 561 & 584 & 571 \\
\hline $\mathrm{Kg} / \mathrm{Ca} /$ day & 1.35 & 1.67 & 1.60 & 1.56 \\
\hline
\end{tabular}


In 2014, the municipalities collected 207.485 tons of waste in Guadeloupe, which corresponds to $1.41 \mathrm{~kg}$ per capita per day.

Table 2. Composition of waste in Guadeloupe (2011) [1]

\begin{tabular}{|c|c|c|}
\hline Categories & $\mathrm{Kg} / \mathrm{Ca} / \mathrm{y}$ Par & $32.7 \%$ \\
\hline Organic waste & 130.2 & $8.7 \%$ \\
\hline Papers & 34.8 & $9.3 \%$ \\
\hline Cartons & 37 & $3.0 \%$ \\
\hline Complex/composites & 12 & $2.2 \%$ \\
\hline Textiles & 8.8 & $8.0 \%$ \\
\hline Sanitary textiles & 31.9 & $11.8 \%$ \\
\hline Plastics & 47.1 & $2.6 \%$ \\
\hline Fuels not classified & 10.3 & $10.8 \%$ \\
\hline Glass & 43.1 & $5.4 \%$ \\
\hline Metals & 21.5 & $1.4 \%$ \\
\hline Noncombardible Not classified & 5.4 & $0.7 \%$ \\
\hline Purpose elements & 2.9 & $3.2 \%$ \\
\hline Total & 12.9 & $100 \%$ \\
\hline
\end{tabular}

\subsection{Truitier's Landfill}

The site of Truitier is an open landfill, not controlled, in operation since approximately 35 years. Truitier's landfill is an unsealed landfill, which means there is no geo-membrane layer to prevent leachate contact in the soil and groundwater. Most of the uncontrolled and unsealed landfills received wastes containing petroleum substances and hazardous substances that have a greater impact on groundwater. For Truitier site, leachate, oil residue and dangerous waste produce the most important threat to the environment, the results of this study are, in many ways, much better than for most unsealed landfills where indiscriminate disposal of waste occurred. According to an environmental assessment study of this site, fortunately, the soil lithology is generally dense, as the soils are clayey and contain inter-stratified sand. This type of soil appears to act as a natural liner, which controls leachate from the landfill in the environment and avoids groundwater contamination [5].

It is located, 3,5km North-West of the Port-au-Prince airport and less than $690 \mathrm{~m}$ from the Atlantic Ocean. In fact, it is situated neighboring to the ecosystem suffering the effects of tide $(300 \mathrm{~m})$. The landfill extends on an area of around 250 ha [5].

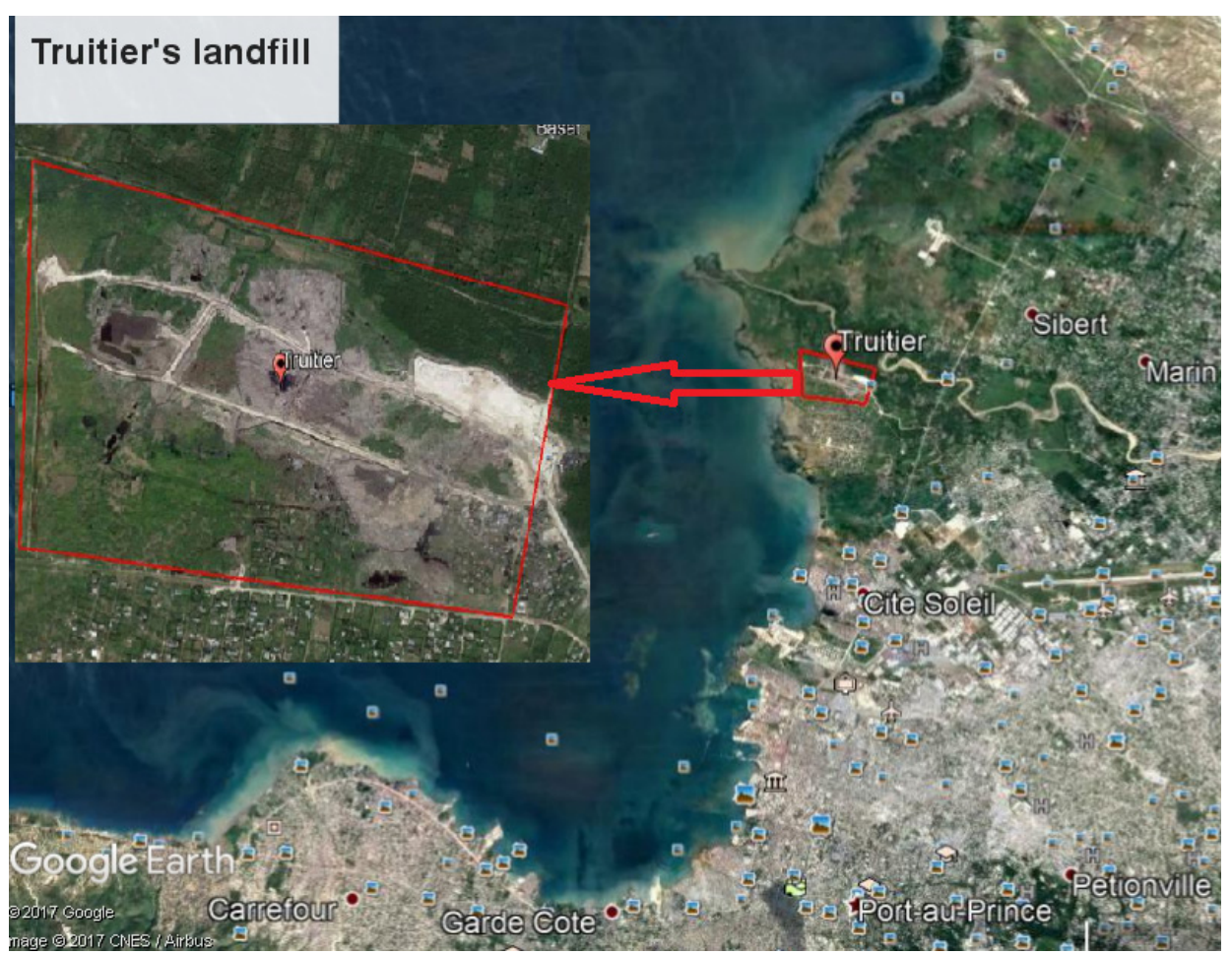

Figure 2. Truitier's landfill location 
According to the studies conducted by the French Research group "Le Groupe de Recherche des Echanges Technologiques" (GRET) in September 1996 and in May 2002[10], the production per day and per capita of household waste in disadvantaged neighborhoods, was respectively 0.7 and $0.8 \mathrm{~kg} / \mathrm{ca} /$ day. In effect, residential neighborhoods garbage has not been selected. Taken in account this type of waste, a production per capita of 1 $\mathrm{kg} / \mathrm{ca} /$ day was obtained. In 2006, only for Port-au-Prince a population has been estimated at about 2.5 million inhabitants. This corresponds to an estimated production of 2500 tons/day and 912,500 tons of waste per year. Taking into account the other types of waste such as demolition waste, agricultural waste, industrial waste, medical waste, waste assimilated etc., it was more than 2.75 million tons of waste per year.

In 2016, the number of population living in Port-au-Prince has strongly increased. It reached 3 million inhabitants. So, the overall production of waste would exceed 5 million tons for 2016 .

\subsection{Composition of the Waste in Haiti}

Table 3. Composition of household waste in Haiti

\begin{tabular}{|c|c|c|}
\hline Categories & $\mathrm{Kg} / \mathrm{Ca} /$ year & Percentage \\
\hline Organic matter & 193.45 & $53 \%$ \\
\hline Plastic & 54.75 & $15 \%$ \\
\hline Paper & 43.8 & $12 \%$ \\
\hline Textiles & 25.55 & $7 \%$ \\
\hline Debris & 14.6 & $4 \%$ \\
\hline Metal & 7.3 & $2 \%$ \\
\hline Glass & 7.3 & $2 \%$ \\
\hline Wood & 7.3 & $2 \%$ \\
\hline Other & 10.95 & $3 \%$ \\
\hline Total & 365 & $100 \%$ \\
\hline
\end{tabular}

The household wastes have a high content of organic matter. According to the Technical ReportUNDP/MTPTC-UGDS-L2, the composition of waste at Truitier's landfill carried out an organic fraction of waste estimated at 53\%. Papers, cartons, plastics and metals represented a percentage of $30 \%$.

\subsection{The Gas from Landfills}

In spite of the heterogeneity of a landfill to another, the main emitted gases are always the same. The methane $\left(\mathrm{CH}_{4}\right)$ and the carbonic gas $\left(\mathrm{CO}_{2}\right)$ are found in very high proportions. Other gases as the oxygen $\left(\mathrm{O}_{2}\right)$, nitrogen $\left(\mathrm{N}_{2}\right)$, water vapor $\left(\mathrm{H}_{2} \mathrm{O}\right)$, are also present in lowest proportions). Gases in trace concentrations, like mercaptans and Volatile Organic Compounds (VOCS), are also present.

Truitier's landfill is the single official waste deposition site of the Port-au-Prince city. It is a non-waterproof dump, a disease vector and a source of pollutant. Several ragmen live in the landfill [18]. They regularly put the fire in the waste, causing air pollution [10]. There represent a non-negligible risk to human health. The combustion of waste, releases into the atmosphere, gases very harmful, such as: the carbon monoxide $(\mathrm{CO})$, carbon dioxide $\left(\mathrm{CO}_{2}\right)$ with soot particles.

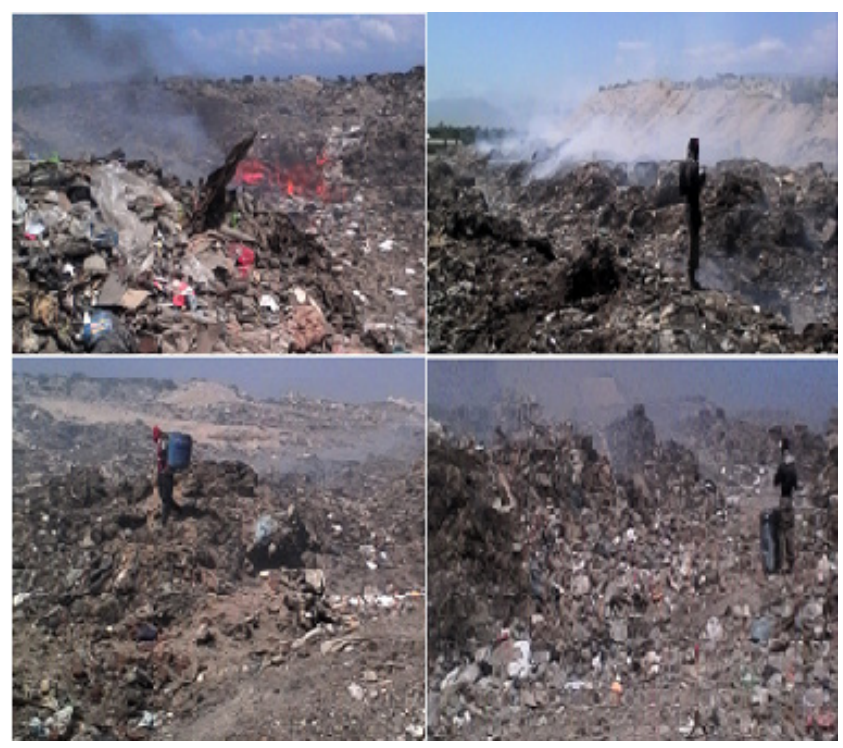

Figure 3. Fire in the landfill's Truitier

Unlike Truitier's landfill is a site not controlled, the Gabarre's landfill is a controlled landfill in progress of rehabilitation. At Gabarre's landfill the waste's water are drained in channels toward the basin of leachate, for treatment. The biogases are channeled into pipeline to a device, called Flare, in order to burn them. Nevertheless, a proportion of biogas from the landfill is spread in the air and impacts the surrounding neighborhoods.

In the Gabarre's landfill, they class the following waste taking in account their ages. The new waste on one side and let the old waste on the other side. The older waste, even are already rehabilitated. 


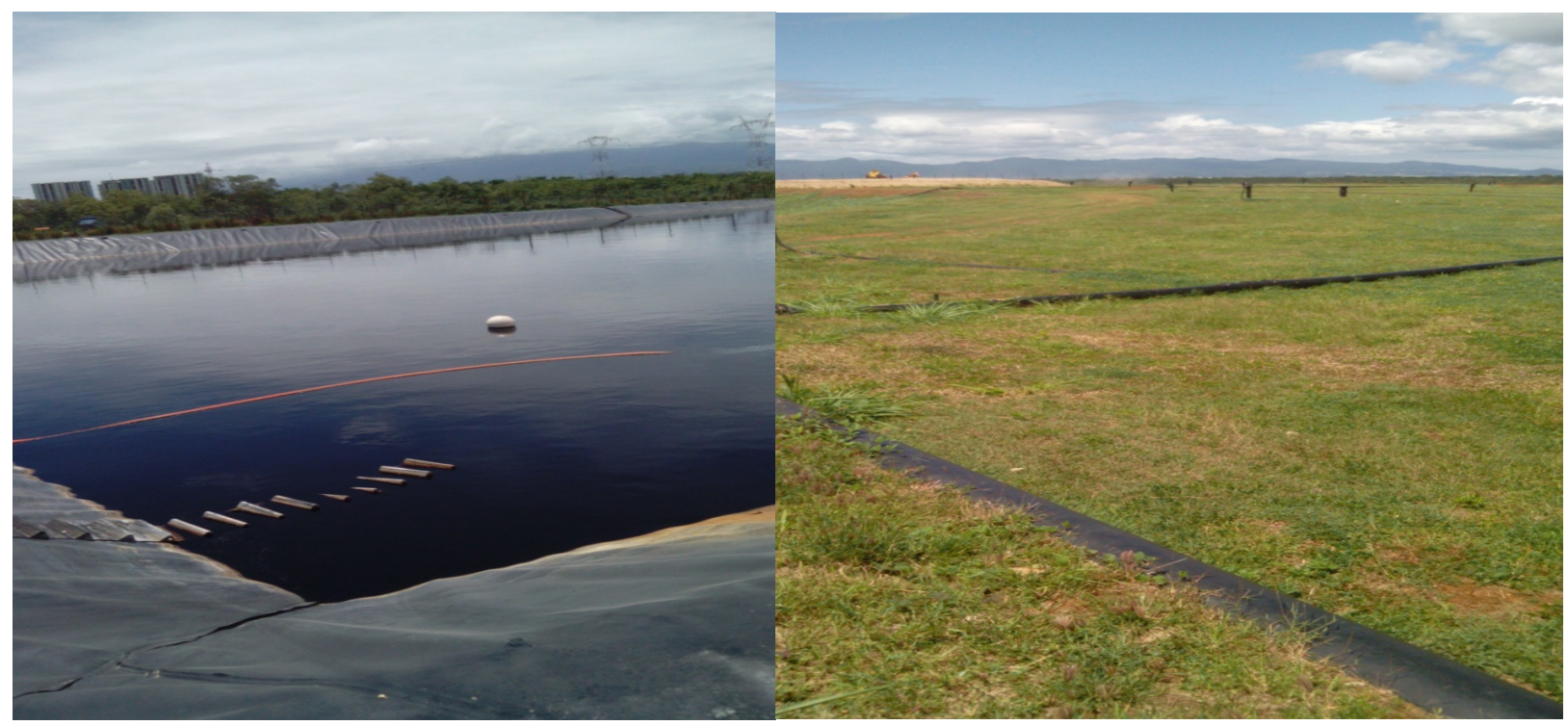

Figure 4. The Basin of leachate from the Gabarre's landfill and line pipe of biogas.

\section{Gas Measures}

\subsection{Measurement Materials}

To carry out our goal, we have selected a set of measurement point. The measurement points were chosen following the direction of the wind, because the pollutants of the landfill have been carried to the surrounding neighborhoods by the wind.
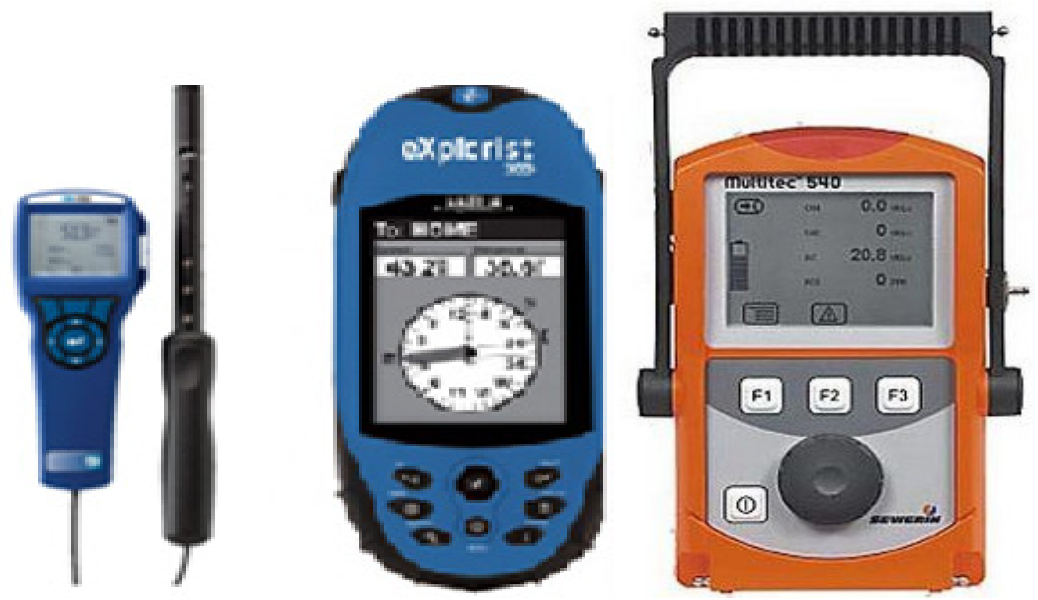

Figure 5. Left a sensor, in the middle a GPS, to the right, the device of measurement of biogas

The two most important apparatus used during the gas measurement campaigns were an IAQ Calc 7545 of TSI industry for the $\mathrm{CO}_{2}$ concentration and the humidity level, and a Multitec 540 sensor from Sewerin. The last one performed measures of five gases: $\mathrm{CH}_{4}, \mathrm{CO}_{2}, \mathrm{H}_{2} \mathrm{~S}, \mathrm{O}_{2}, \mathrm{CO}$. In addition, just in the middle of the figure 5, we used a GPS to know the position of the measurement points. All the devices are wireless which helpful on campaign field but with difficulties on a long temporal using.

\subsection{Measurement Campaign Fields}

Our measurement campaign was held in Guadeloupe and Haiti, we have selected a number of measurement point to be able to observe the evolution of gas from landfills. After a first measurement campaign the higher concentration point have been chose to make a continuous measurement, in order to found the evolution of the emission of hydrogen sulphide 
at the level of the landfill and the surroundings of the site. As they can be observed, on the Figure 6, the height points have been chosen leeward of the Gabarre landfill.

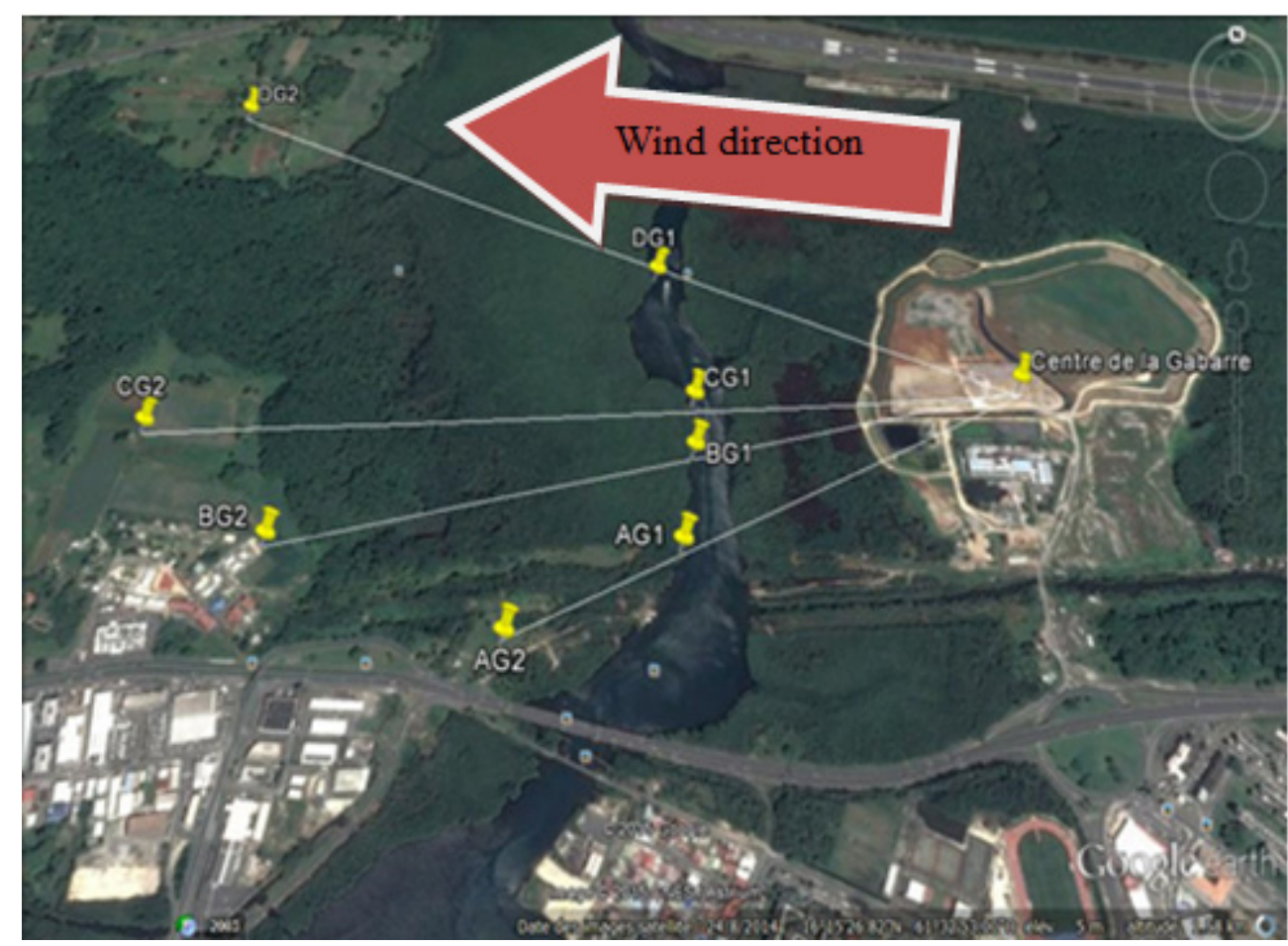

Figure 6. Gabarre's landfill, measurement points and wind direction.

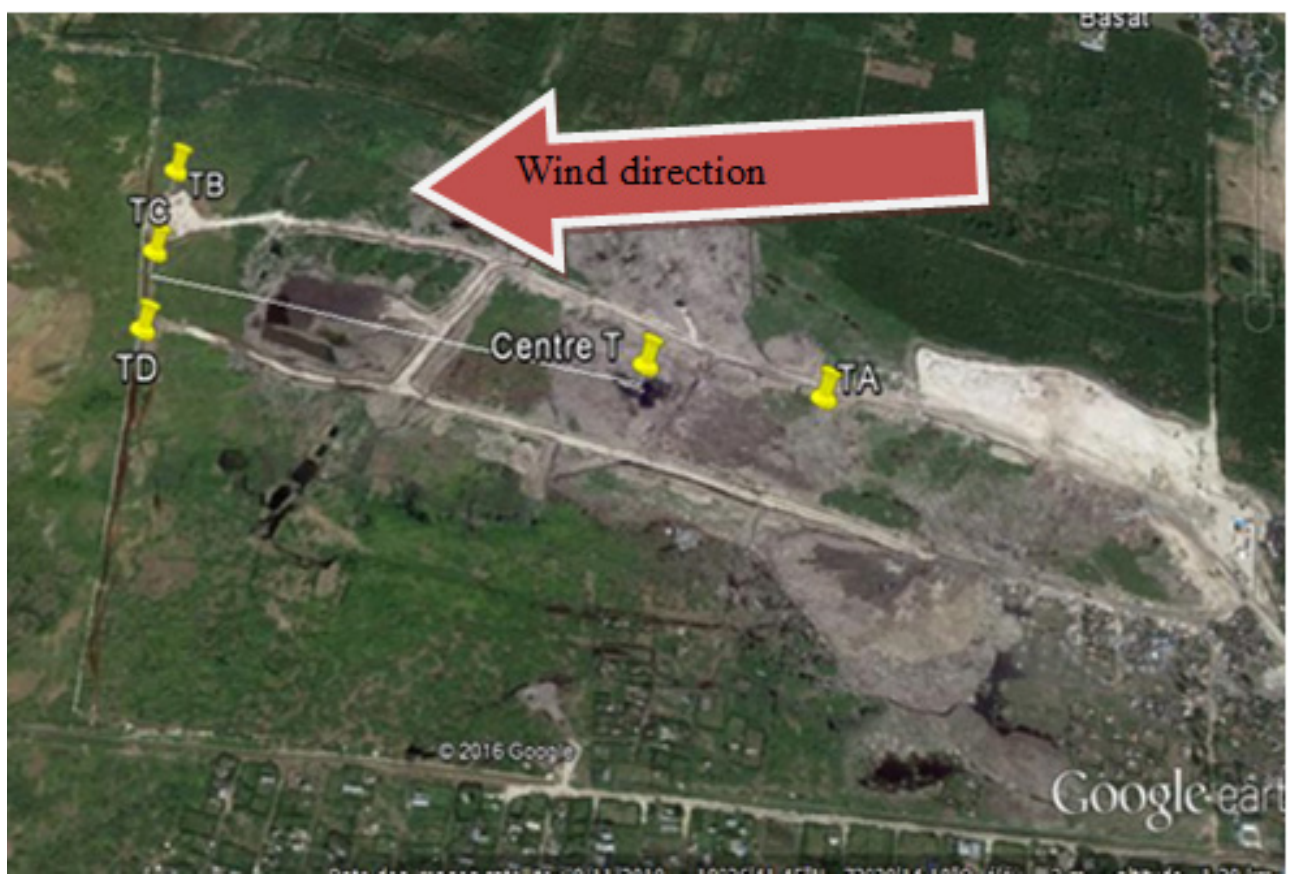

Figure 7. Truitier's landfill, measurement points and wind direction

On Truitier's campaign field, five points have been used with the possibility two performed measures in the middle of the garbage with Points $\mathrm{T}_{\mathbf{A}}$ and $\mathrm{T}$ (Fig. 7). 


\subsection{Evolution of Hydrogen Sulphide $\left(\mathrm{H}_{2} \mathrm{~S}\right)$}

The evolution of hydrogen sulphide $\left(\mathrm{H}_{2} \mathrm{~S}\right)$ depends on several parameters setting in the game, such as the temperature, humidity, wind speed etc.

We carried out biogas measurements in all the points identified on the diagram, after several measurement sequences per point; we identified the point where the concentration of hydrogen sulphide is higher. The $\mathrm{H}_{2} \mathrm{~S}$ higher concentration was obtained for $\mathrm{D}_{\mathbf{G} 2}$ measure point. It is location North-West of the Gabarre area. In Truitier case the maximum gas concentration was found at the $T_{C}$ position. In both points, continuous measurements during one day were done.

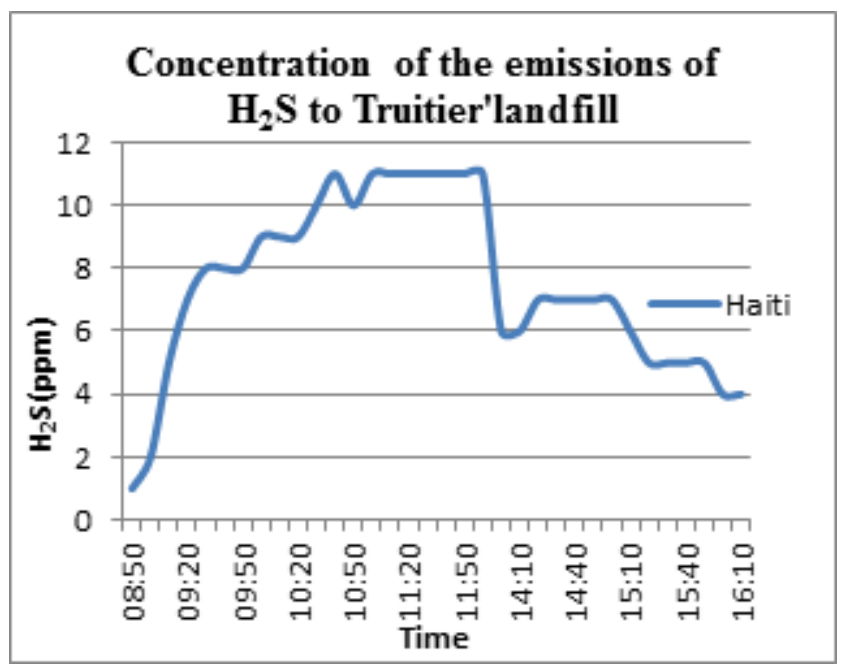

Figure 8. Concentrations of the issuance of $\mathrm{H} 2 \mathrm{~S}$ in time function at $\mathrm{T}_{\mathbf{C}}$ point.

The graph of Figure 8 gives the behavior of hydrogen sulphide $\left(\mathrm{H}_{2} \mathrm{~S}\right)$ in function of time, which is related to the release of $\mathrm{H}_{2} \mathrm{~S}$ from the Truitier's landfill in Port-au-Prince.

By safety for the performer, in Truitier, the measurements cannot begin before $8 \mathrm{~h} 30$. The data recording began at $8 \mathrm{~h} 40$ and gases concentrations were registered every 10 minutes. The diurnal belt shape observed on Figure 8, reached a maximum daily value of $11 \mathrm{ppm}$ around midday. In the morning a gas concentration increase is observed step by step and an opposite behavior is noted during the afternoon. It suggest that, the gas release is powered by incoming heat energy from the sun. In this case, probably, the nocturnal spread of $\mathrm{H}_{2} \mathrm{~S}$ is negligible.

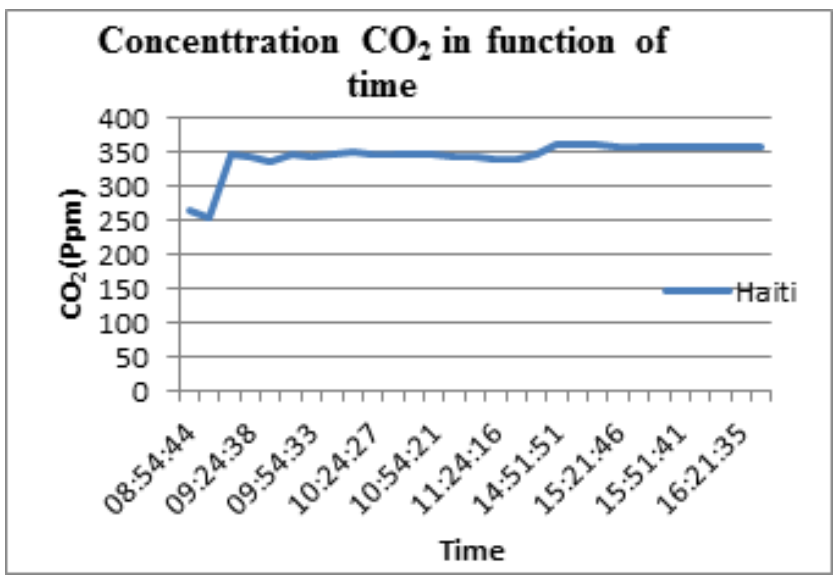

Figure 9. Concentrations of the emission of $\mathrm{CO}_{2}$ at $\mathrm{T}_{\mathrm{C}}$ point in function of time.

On the opposite, the curve given the behavior of $\mathrm{CO}_{2}$ along the time at the Truitier's landfill (Fig. 9), shows a quasi-constant value around $350 \mathrm{ppm}$, suggesting a constant impact of the landfill in ambient air concentration. The low $\mathrm{CO}_{2}$ concentrations in the beginning of the measurements campaign probably reveal the $\mathrm{CO}_{2}$ level of the background. The gas measurements have been performed during Wednesday, August the $24^{\text {th }}$ of 2016 which is a sunny day with a constant trade wind.

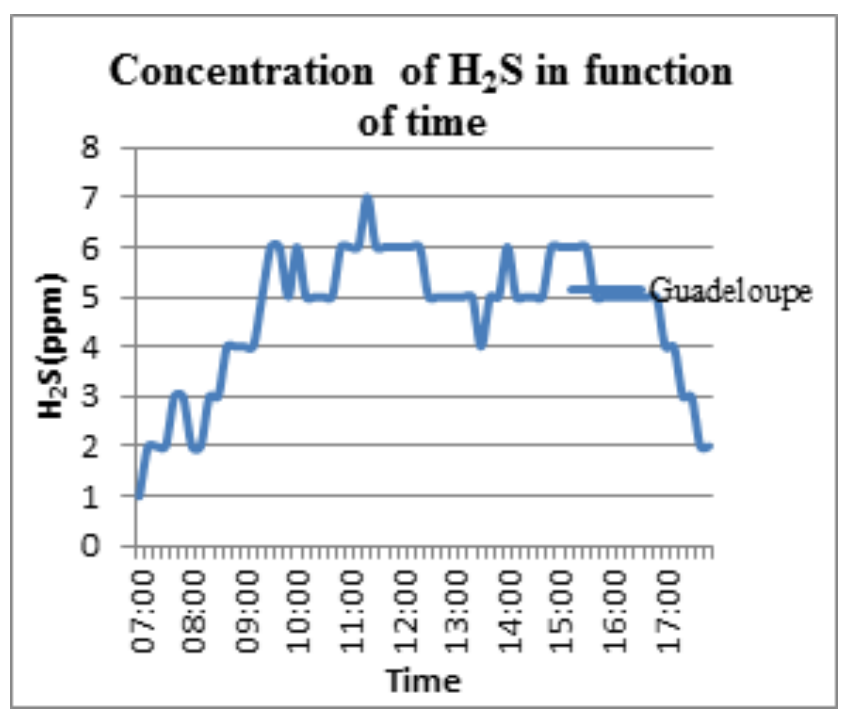

Figure 10. Concentrations of hydrogen sulphide evolution in the vicinity of the Gabarre's landfill 
The measure campaign in Guadeloupe was done with the same process than the first one held in Port au Prince. The continuous measurements began very soon in the morning and finished in the early evening. A belt shape behavior is observed on the figure 10 . The small decrease registered between midday and $2 \mathrm{pm}$ is related to an apparatus stop due to empty battery. The maximum concentration reached 7 ppm just before midday. This behavior seems to be the same than the behavior observed in Truitier landfill. Some verification has been done in Guadeloupe at night related to the safety of the measure point. $\mathrm{A}_{2} \mathrm{~S}$ concentration close to zero was found at 9:00 pm. The classic behavior of $\mathrm{H}_{2} \mathrm{~S}$ concentration in the vicinity of the Gabarre's landfill begin by an increase from zero before the sun rise to a maximum around midday, followed by a decrease in the afternoon reaching zero at nightfall[11]. An implication of two processes seems to drive this behavior. On one hand the emissivity with the heat energy of the sun and in the other side a modification of the wind direction related to land breeze and sea breeze permutation.

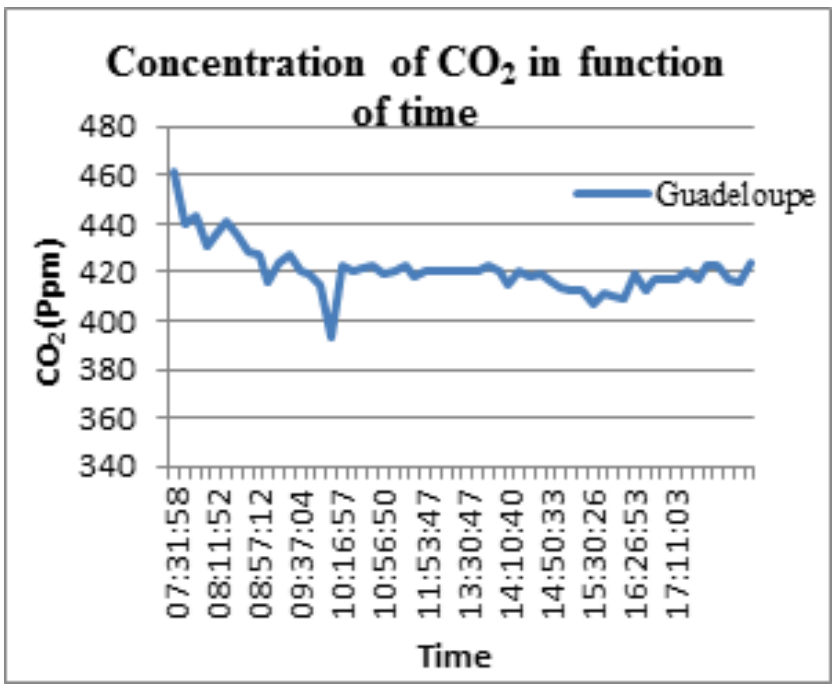

Figure 11. The Evolution of the concentration of carbon dioxide $\left(\mathrm{CO}_{2}\right)$ as a function of time

The Figure 11 presenting the $\mathrm{CO}_{2}$ concentration suggests an emissivity impact of the neighboring main road. The traffic jean is in a higher level in the early morning. A quasi constant level is observed until 4:00 pm followed by an increase linked to the densification of the car traffic after work. Probably the emission of the landfill is drowning in the spread of $\mathrm{CO}_{2}$ by the road.

During the Guadeloupe campaign the weather was good with sun shine and constant trade wind.

\section{Global Emissivity Evaluation of the Two Landfills}

Using, the plume Gaussian model for the atmospheric dispersion and inversing the equation, the following expression for the emissivity of the Hydrogen sulphide by the landfill was found:

$$
Q_{H_{2} S}=C \frac{2 \pi U \sigma_{y} \sigma_{z}}{e^{-\alpha}\left(e^{-\beta}+e^{-\gamma}\right)}
$$

$\mathrm{C}$ : The concentration of hydrogen sulphide in $\mathrm{kg} / \mathrm{m}^{3}$

Q: The emissivity in $\mathrm{kg} / \mathrm{s}$

$\mathrm{U}$ : the speed in $\mathrm{m} / \mathrm{s}$

$\sigma y, \sigma z:$ The standard deviations of the Gaussian distribution in meter(m).

According to the stability classes of Pasquill [15], a parameterization used was for a moderate instability with a speed between 2 and $3 \mathrm{~m} / \mathrm{s}$. In that case:

$$
\sigma=a x^{b}+c
$$

Using this equation the both standard deviation were obtained:

$\sigma_{y} \quad: \quad a=0.155 ; b=0.889 ; c=0 \sigma_{z} \quad: \quad a=$ $0.103 ; b=1.11 ; c=0 \alpha, \beta, \Upsilon$ : are of quantities without Units

Where

$$
\begin{aligned}
\alpha=\frac{(y-y o)^{2}}{2 \sigma y^{2}}, \beta & =\frac{(z-z o)^{2}}{2 \sigma z^{2}}, \gamma=\frac{(z+z o)^{2}}{2 \sigma z^{2}} \\
h & =h_{s}+\Delta h
\end{aligned}
$$

With $\mathrm{z}=\mathrm{h}$ : Effective stack height

$h_{s}:$ Stack height $(\mathrm{m})$

$\Delta h:$ Plume rise $(\mathrm{m})$

The effective stack height is taken to be the sum of the actual stack height $\mathrm{h}$, and the plume rise. $\Delta h$, defined as the height at which the plume become passive and subsequently follows the ambient air motion. The gases are released at temperatures hotter than the ambient air.

Extra height of a hot plume, example of Briggs's formulas (1972) [4]:

$$
\Delta h=38,71 \frac{\left(\frac{g w d^{2} \Delta T}{4 T_{S}}\right)^{3 / 5}}{U}
$$

W: gas exit velocity; Ts: gas temperature at the outlet of

\begin{tabular}{|c|c|c|}
\hline Symbol & Value/unit & comment \\
\hline W & $2.5 \mathrm{~cm} / \mathrm{s}$ & $\begin{array}{c}2.5 \mathrm{~cm} / \mathrm{s} \text { was chosen to compensate } \\
\text { the normal subsidence air }\end{array}$ \\
\hline \multirow[b]{2}{*}{$T_{s}$} & 313K in Haiti & \multirow{2}{*}{$\begin{array}{l}\text { gas temperature at the outlet of the } \\
\text { chimney }\end{array}$} \\
\hline & 308K in Guadeloupe & \\
\hline \multirow{2}{*}{$T_{\text {air }}$} & $303 \mathrm{~K}$ in Haiti & \multirow{2}{*}{ Temperature of the ambient air. } \\
\hline & $301 \mathrm{~K}$ in Guadeloupe & \\
\hline \multirow[b]{2}{*}{$\Delta T$} & $283 \mathrm{~K}$ in Haiti & \multirow{2}{*}{$\begin{array}{l}\text { Is the difference temperature } \\
\text { between gas temperature at the outlet } \\
\text { of the chimney and the temperature } \\
\text { of the ambient air. }\end{array}$} \\
\hline & $280 \mathrm{~K}$ in Guadeloupe & \\
\hline \multirow{2}{*}{$\mathrm{U}$} & $1.7 \mathrm{~m} / \mathrm{s}$ & \multirow{2}{*}{$\begin{array}{l}\text { Wind speed at the measuring } \\
\text { point.(windyty.com) }\end{array}$} \\
\hline & $2.77 \mathrm{~m} / \mathrm{s}$ & \\
\hline $\mathrm{d}$ & $2 \mathrm{~cm}$ & Diameter of the chimney \\
\hline$g$ & $9.81 \mathrm{~ms}^{-2}$ & Intensity of the gravity \\
\hline
\end{tabular}
the chimney; $\Delta T$ : Temperature difference between air and Ts; U: Wind speed at the height of the chimney; $g$ : Intensity of gravity.

Table 4. Data of the symbols and commentary 
The previous expression allows us to determine the emissivity of $\mathrm{H}_{2} \mathrm{~S}$ emits by the landfill.

In fact, thanks to this formula we can deduce the emissivity of $\mathrm{H}_{2} \mathrm{~S}$ in the surrounding areas of the landfill and in the center of the landfill.

\subsection{Truitier's Landfill}

After measurements made in the various points of the landfill, we chose the $T_{\mathbf{C}}$ point to make continuous measurements, it is one of the strategic point measurements on this site. A point under the direction of the wind during our measurement, the wind brings a set of pollutant according to its direction. From the concentration find at this point it is obvious to find its emissivity by the inverse Gaussian method.

$\mathrm{T}_{\mathbf{C}}$ point coordinates at Truitier's landfill $(570.98 \mathrm{~m}$; $74.16 \mathrm{~m} ; 10.04 \mathrm{~m})$.

Table 5. Emissivity of hydrogen sulphide $\left(\mathrm{H}_{2} \mathrm{~S}\right)$ at $\mathrm{T}_{\mathbf{C}}$ point

\begin{tabular}{|c|c|c|}
\hline Speed $(\mathrm{m} / \mathrm{s})$ & Concentration $\left(\mathrm{Kg} / \mathrm{m}^{3}\right)$ & (Emissivity $\mathrm{kg} / \mathrm{s})$ \\
\hline 2.67 & $12.6 \times 10^{-6}$ & 4.60 \\
\hline 2.67 & $11.2 \times 10^{-6}$ & 4.09 \\
\hline 3 & $15.4 \times 10^{-6}$ & 6.31 \\
\hline 3 & $7 \times 10^{-6}$ & 2.86 \\
\hline
\end{tabular}

NB: $1 \mathrm{ppm}$ of hydrogen sulphide $=1.4 \mathrm{mg} / \mathrm{m}^{3}$

For the same wind speed, when the concentration increases, the emissivity is also increased. In effect, the emissivity is proportional to the concentration of the gas, where the relationship of proportionality:

$$
\begin{gathered}
Q=C \frac{1}{K} U \text { and } \\
\frac{1}{K}=\frac{2 \pi \sigma_{y} \sigma_{z}}{e^{-\alpha}\left(e^{-\beta}+e^{-\gamma}\right)}
\end{gathered}
$$

\subsection{Gabarre's Landfill}

$\mathrm{D}_{\mathbf{G} 2}$ is a point where all pollutants from the Gabarre are concentrated. This point is not only under the direction of the landfill's wind, but also it is a point that captures the overall emissivity of the Gabarre in relation to the distance where it is located. As at $T_{\mathbf{C}}$ point, a continuous measurement was made at $\mathrm{D}_{\mathbf{G} 2}$ to be able to observe the evolution of the concentration of hydrogen sulphide at this point during one day. With the concentration found, it's clear to find the emissivity by the inverse Gaussian method.

$\mathrm{D}_{\mathrm{G} 2}$ point coordinates at Gabarre's landfill (1613m; $729 \mathrm{~m} ; 12.02 \mathrm{~m})$.

Table 6. Emissivity of hydrogen sulphide $\left(\mathrm{H}_{2} \mathrm{~S}\right)$ at $\mathrm{D}_{\mathrm{G} 2}$ point

\begin{tabular}{|c|c|c|}
\hline Speed $(\mathrm{m} / \mathrm{s})$ & Concentration $\left(\mathrm{Kg} / \mathrm{m}^{3}\right)$ & Emissivity $(\mathrm{Kg} / \mathrm{s})$ \\
\hline 2 & $2.8 \times 10^{-6}$ & $4.73 \times 10^{9}$ \\
\hline 2 & $4.2 \times 10^{-6}$ & $7.11 \times 10^{9}$ \\
\hline 3 & $7 \times 10^{-6}$ & $17.76 \times 10^{9}$ \\
\hline 3 & $8.4 \times 10^{-6}$ & $21.32 \times 10^{9}$ \\
\hline
\end{tabular}

\subsection{Comparison of Gabarre's Landfill and Truitier's Landfill Emissivity}

The concentration of $\mathrm{H}_{2} \mathrm{~S}$ in the Gabarre's landfill, assuming that Truitier's landfill emitted as Gabarre at point $\mathrm{D}_{\mathrm{G} 2}(1613 \mathrm{~m}, 729 \mathrm{~m}$ and $12.02 \mathrm{~m})$. That's to say, in place of Gabarre we put Truitier, and then we calculate the concentration of $\mathrm{H}_{2} \mathrm{~S}$ found at $\mathrm{D}_{\mathbf{G} 2}$ point of Gabarre.

Table 7. $\mathrm{H}_{2} \mathrm{~S}$ Concentration of the Gabarre's landfill

\begin{tabular}{|c|c|c|}
\hline $\begin{array}{c}\text { Speed } \\
(\mathrm{m} / \mathrm{s})\end{array}$ & $\begin{array}{c}\text { Truitier's Emissivity } \\
(\mathrm{kg} / \mathrm{s})\end{array}$ & $\begin{array}{c}\text { Gabarre's concentration } \\
\left(\mathrm{Kg} / \mathrm{m}^{3}\right)\end{array}$ \\
\hline 2 & 4.60 & $2.72 \times 10^{-15}$ \\
\hline 2 & 4.09 & $2.42 \times 10^{-15}$ \\
\hline 3 & 6.31 & $2.48 \times 10^{-15}$ \\
\hline 3 & 2.86 & $1.13 \times 10^{-15}$ \\
\hline
\end{tabular}

Now we determine the concentration of $\mathrm{H}_{2} \mathrm{~S}$ in Truitier's landfill, assuming that Gabarre's landfill emitted as Truitier at point $\mathrm{T}_{\mathrm{C}}(570.98 \mathrm{~m} ; 74.16 \mathrm{~m} ; 10.04 \mathrm{~m})$. That's to say, in place of Truitier we put Gabarre, and then we calculate the concentration of $\mathrm{H}_{2} \mathrm{~S}$ found at $\mathrm{T}_{\mathbf{C}}$ point of Truitier.

Table 8. $\mathrm{H}_{2} \mathrm{~S}$ concentration of the Truitier's landfill

\begin{tabular}{|c|c|c|}
\hline $\begin{array}{c}\text { Speed } \\
(\mathrm{m} / \mathrm{s})\end{array}$ & $\begin{array}{c}\text { Gabarre's emissivity } \\
(\mathrm{Kg} / \mathrm{s})\end{array}$ & $\begin{array}{c}\text { Truitier's concentration } \\
\left(\mathrm{Kg} / \mathrm{m}^{3}\right)\end{array}$ \\
\hline 2.67 & $4.73 \times 10^{9}$ & $1.29 \times 10^{4}$ \\
\hline 2.67 & $7.11 \times 10^{9}$ & $1.94 \times 10^{4}$ \\
\hline 3 & $17.76 \times 10^{9}$ & $6.5 \times 10^{4}$ \\
\hline 3 & $21.32 \times 10^{9}$ & $8.5 \times 10^{4}$ \\
\hline
\end{tabular}

To compare the two landfills behavior, two concentrations have been calculated, one for $\mathrm{D}_{\mathrm{G} 2}$ point in Guadeloupe using the emissivity of Truitier positioned in the center Gabare's landfill, the other in Truitier using the emissivity of Gabare positioned in the middle of Truitier's Landfill. At $\mathrm{D}_{\mathrm{G} 2}$ point the concentration will be almost zero $\left(10^{-15}\right)$. On the other hand, In Truitier landfill at appoint located $570.98 \mathrm{~m}$ from the center, a $\mathrm{H}_{2} \mathrm{~S}$ gaz concentration around $10^{4}$ is obtained.

Related to their histories, their dimensions and their garbage managements the two landfills are very different. This is a non-expected result because Gabare is smaller landfill with ongoing rehabilitation and it produces more gases than the uncontrolled landfill of Truitier.

This can be due to the destruction of the layers of geo textile membrane used for the rehabilitation Gabarre's landfill. The geo textile membranes have duration of life. Probably be the layer geo textile membrane of Gabarre's landfill has been altered by pests and is no longer waterproof. Generally the geo membrane is ruptured during the filling of the site, and biogas which is form contain malodorous and explosives gases. It is likely to cause fires (subsurface pollution), which can burn the geo membranes, from where the disappearance of this layer of sealing of the landfill with the aquifers and the direct contact of leachate with the ground. Finally the landfills 
using the geo textile membranes as sealing coating are not secure landfills.

Table 9. Threshold of toxicity of hydrogen sulphide in Europe and America on 8h of work [6]

\begin{tabular}{|c|c|c|}
\hline Continent & Europe & America \\
\hline Threshold toxicity & $5 \mathrm{ppm}=7 \mathrm{mg} / \mathrm{m}^{3}$ & $1 \mathrm{ppm}=1.4 \mathrm{mg} / \mathrm{m}^{3}$ \\
\hline
\end{tabular}

\section{Conclusions}

Despite the negative consequences of the other gases on the environment and human health, the hydrogen sulphide $\left(\mathrm{H}_{2} \mathrm{~S}\right)$ request special attention. By contrast, the concentration of hydrogen $\left(\mathrm{H}_{2} \mathrm{~S}\right)$ has exceeded the average value of the occupational exposure, to this value represents a danger for the population. We found a concentration of hydrogen sulphide $\left(\mathrm{H}_{2} \mathrm{~S}\right)$, it's $11 \mathrm{ppm}$ in the air of Truitier's landfill, a figure very representative which is higher than the limit value for occupational exposure(OELS) on $8 \mathrm{~h}$ of work in America and also in Europe, even for values in the short term (15minutes). Despite the significant value of the hydrogen sulphide $\left(\mathrm{H}_{2} \mathrm{~S}\right)$ in the air of Truitier's landfill, the calculation of the total emissivity of the Gabarre's landfill reduced to the center is higher than Truitier's landfill emissivity. The strong presence of the ragman of the informal sector on the site of Truitier's landfill, likely decreases the share of fermentable gas. They have put spontaneously fire on the site of Truitier so that they can recover the waste recycling and reusable [18]. In effect, the burning of waste on the site of Truitier's landfill decreases the concentration of certain gas such as hydrogen sulphide $\left(\mathrm{H}_{2} \mathrm{~S}\right)$ but probably increases the concentration of particles and other gases such as greenhouse gases. Those gases participate in the planetary warming.

The prospects are of two orders:

1. Propose solutions to improve the management of waste (collection and treatment),

2. Evaluate the correlations between $\mathrm{H}_{2} \mathrm{~S}$ and VOCs in order to measure the impact of the proposed solutions for the treatment of waste. It should also measure VOCs, because the VOCs are highly carcinogenic or even mutagenic.

\section{REFERENCES}

[1] ADEME, Campagne de caractérisation des déchets ménagers et assimilées de la Guadeloupe. Préparé et présenté par ebhys/Technologies de l'environnement et ECODEC. Août 2012

[2] C. David Cooper, Civil, Envir; and Constr. Engr. Dept; UCF, 4000 Central Florida Blvd, Orlando, Florida 32816-2450. Modeling to determine $\mathrm{H}_{2} \mathrm{~S}$ Emissions and dispersion from Florida C\&D landfills (2010).
[3] EPA (United States Environmental Protection Agency). Best management practices to prevent and control hydrogen sulfide and reduced sulfur compound emissions at landfills that dispose of Gypsum drywall.- EPA/600/R-14/039/Augu st2014/www.epa.gov/researh.

[4] Hadjira Schmitt-Foudhil. Dispersion atmosphérique. Module environnement atmosphérique et qualité de l'air. Cerea(2010).

[5] Integrity Disaster Consultants - LLC 5751 Miami Lakes, FL 33016. Etude environnementale de référence, rapport d'évaluation du site pour la décharge de Truitier, Port-au-Prince, Haïti. Décembre 2010. Projet de IDC $\mathrm{N}^{\circ}$ : 2010-9001.

[6] INRS. Base de données fiches toxicologiques sulfure d'hydrogène. fiche toxicologique $\mathrm{n}^{\circ} 32$ (2014).

[7] Lilliana Abarca Guerrero et al. Solid waste management challenges for cities in developing countries. 23 october 2012.

[8] Mei Sun, Wenjie Sun, Morton A.Barlaz. A batch assay to measure microbial hydrogen sulfide production from sulfur containing solid wastes. 11 February 2016.

[9] Observatoire des déchets de la Guadeloupe. Les chiffres clés des déchets en Guadeloupe(2014). Publication 2015 page11.

[10] Olga Samper et al. Analyse de la problématique des déchets solides dans la zone métropolitaine de Port-au-Prince. Rapport intérimaire. 10/12/2006.

[11] Pierre-Georges V., J. Molinie, C.Bassette, F. Bade, P. Nuiro, "Hourly repartition of hydrogen sulphide from gas measure downwind of a landfill", Air Quality 2016, 14-18 March, Milan, Italy.

[12] Plocoste T, Koaly SJ, Petit RH, Roussas A (2016) Estimation of Methane Emission from a Waste Dome in a Tropical Insular Area. Int J. Waste Resour 6: 211. doi:10.4172/2252-5211.1000211.

[13] Rodica chiriac et al. Characterization of VOCs emitted by open cells receiving municipal solid waste. 1 august 2007.

[14] S. Sakai et al. World trends in municipal solid waste management. Waste management vol 16, Nos5/6, pp. 341-350, 1996. 1997 Elsevier science Ltd.

[15] Seinfeld, J.H. and Pandis, S.N. (2006) Atmospheric Chemistry and Physics: From Air Pollution to Climate Change. 2nd Edition, John Wiley \& Sons, New York.

[16] SYVADE. Valoriser vos déchets, c'est notre nature. www.syvadeguadeloupe.fr/le-sictom

[17] T. Plocoste et al. Evidence of the effect of an urban heat island on air quality near a landfill/ urban climate 10 (2014) $745-757$.

[18] Verdieu P.G. "Evaluation of gases from garbage dump of Truitier in Haiti", ISWA-SWIS Winter School 2017 on Solid Waste Management, Landfill and Landfill Mining at the University of Texas at Arlington(UTA), the city of Denton and the city of Irving, Texas, USA.

[19] WHO. Environmental Health Criteria 19. Hydrogen sulfide. Geneva, 1981 ISBN 9241540796 